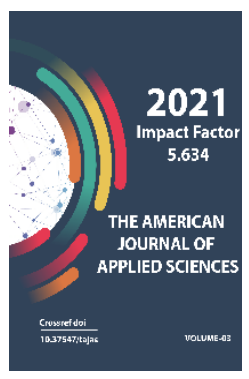

\title{
Ethnodemographic Information As A Source In Population Censes (On The Example Of Uzbekistan)
}

\author{
Saodat Abdurashidovna Toshtemirova \\ Chirchik State Pedagogical Institute Of Tashkent Region, Uzbekistan
}

Journal Website:

http://usajournalshub.c

om/index,php/tajas

Copyright: Original

content from this work

may be used under the

terms of the creative

commons attributes

4.0 licence.

\section{ABSTRACT}

This article analyzes ethno-demographic data, their study and, in turn, is based on population censuses. Historical aspects of ethno-demographic data in population censuses are presented. The analysis of family data in the censuses reflects the historical context of the family's lifestyle and social status, while also focusing on the ethnic composition of the population. An independent final opinion on the topic is given.

\section{KEYWORDS}

Ethnic groups, ethno-demography, nationalities, censuses, national composition, demographic characteristics, social structure, family-marriage relations, family formation, marital status, statistics.

\section{INTRODUCTION}

The history of mankind is the merging of the history of particular groups of the population, social organisms and their interactions. Among them, the group that has a place and importance in the historical process is the ethnic group.

Ethnic demography, or ethno-demography, is a separate discipline formed on the basis of the 
objects of study of ethnography and demography, and studies the characteristics of the reproduction of peoples in relation to socio-economic and historical conditions.

Ethno-demography uses in its research mainly the results of ethnic statistics, census data, special ethno-demographic, cultural and household research. Ethno-demographic research is also based on a number of social and natural sciences (geography, psychology, sociology, demography, anthropology, ecology, medicine, etc.) that study different aspects of ethnic groups. This is because ethnic groups appear to be the object of study of many disciplines.

The study of ethnic groups is of great political, social and demographic importance for every multinational state in the world. The results of a comprehensive study of the traditions, values, demographic characteristics of all peoples living in it serve as a scientific basis for the development of programs of socioeconomic development of states.

The initial census did not cover the entire population of present-day Uzbekistan. The census provides information on the Uzbek, Tajik, Russian, Kazakh, Kyrgyz and Karakalpak ethnic groups in Uzbekistan, their territorial distribution, education and gender composition[1].

The 1926 census in Uzbekistan included 65 ethnic groups, and the 1939, 1959, 1970, 1979, and 1989 censuses reported an increase of more than 120 nationalities. The most accurate information on the national composition of the population of Uzbekistan and their demographic processes is collected through censuses. Such censuses in Uzbekistan were conducted in 1897, 1926, 1939, 1959, 1970, 1979 and 1989.
ANALYSIS OF SCIENTIFIC SOURCES ON THE SUBJECT

Ethno-demographic research has existed as a separate discipline since the twentieth century. In the first half of the twentieth century, the Russian ethnographer M.V.Ptux studied the death process of 11 peoples living in Europe on the basis of the 1897 census[2]. V.I.Kozlov conducted research on ethnic demography and studied the ethno-demography of peoples[3]. S.I.Brooke has created very important ethno-demographic works on the study of the national composition of the world's population, changes in their dynamics and the characteristics of demographic processes [4].

In Uzbekistan, historians and ethnographers have conducted a number of studies to study the demographic characteristics of many ethnic groups living in the country, such as uzbeks, tajiks, kyrgyz, russians, ukrainians, tatars, koreans. Examples are the researches of M.Karakhanov, V.Gentshke, R.Murtazaeva, O.Ata-Mirzaev[5], M.Burieva [6]. These studies mainly study the ethnic composition of the population of Uzbekistan, the number of ethnic groups, family formation, composition and demographic activities.

The fact that the history of ethno-demographic features of Uzbekistan is reflected in the population census also serves as a source for the study of history, changes in the national composition of the population of the country for 1897-1989 are analyzed.

\section{RESEARCH METHODOLOGY}

Censuses were conducted in Uzbekistan in 1897, 1926, 1939, 1959, 1970, 1979 and 1989, which is one of the main sources for studying history. In the study of these sources it is 
advisable to use historical comparisons, logical, demographic and statistical methods.

\section{PURPOSE OF RESEARCH OF THE TOPIC}

The main purpose of studying ethnodemographic data in censuses as a source is to know and analyze the demographic history of the peoples living in Uzbekistan. In this process, the importance of censuses in the study of the demographic history of peoples and their ethno-demographic data are presented and analyzed.

The following tasks have been identified to achieve the goal:

Analysis of ethno-demographic data and research on their study;

Determine the population censuses and their importance in the study of ethno-demographic data;

To study the population censuses in Uzbekistan and the ethnic characteristics of the national composition, population, family, marriage, formation of social groups.

Today, valuable information on the analysis of censuses as the main source in the study of the history of ethno-demographic processes in Uzbekistan and its importance, changes in the national composition of the population of Uzbekistan in 1897-1989, the social structure of peoples, family-marriage relations, the history of family formation as well as the creation of the system has become one of the current issues.

The theoretical significance of the study of censuses serves as a basis for the development of the theory of the laws of manifestation of socio-economic and political conditions as a key factor in the formation of ethno- demographic processes, the impact of factors such as national traditions and values on demographic processes.

The practical significance of these sources is of special importance in the management and maintenance of peaceful coexistence of all peoples in the multinational Republic of Uzbekistan, as well as in the development of socio-economic programs, demographic forecasts, ethno-demographic programs, textbooks.

Detailed information on the marital status of the population by ethnic groups is based on population lists. The role, position and functions of the family in society are of equal importance to all peoples. But its formation features, demographic activity at the current stage of development of society have separate indicators by ethnic groups.

\section{MAIN PART}

It is of great importance to study the family status of the population as a source in the ethno-demographic data provided in the censuses conducted by the Soviet state in the Uzbek SSR in 1897, 1926, 1939, 1959, 1970, 1979 and 1989.

It is well known that in society, people live in a family environment as a family member or on their own, alone. The fact that the population is divided into such groups indicates its marital status. As mentioned above, information on the marital status of the population is collected through a population census. In Uzbekistan at the end of the XIX century and in the XX century there were several censuses, the last of which (to date) was conducted in 1989.

In the population censuses conducted in Uzbekistan over the years, the population is 
The American Journal of Applied sciences

(ISSN - 2689-0992)

Published: April 30, 2021 | Pages: 256-263

divided into three groups according to marital status:

1. Those who live with the family as a family member.

2. Living separately from the family, but maintaining regular contact with the family (This group includes people who have temporarily left the family for long-term study, work and other reasons).

3. Lonely people.

Detailed statistics on the marital status of the population in Uzbekistan are given in the 1939 census. These data show that in 1939, $93.3 \%$ of the population of Uzbekistan were family members, living with the family, and the remaining $6.7 \%$ lived separately from the family. If these figures are compared with the 1989 census data, it becomes clear that there have been significant positive changes in the family structure of the population of the republic. Because in 1939-1989 it can be seen that the share of the population living in a family environment as a family member increased by $2 \%$ and accounted for $95.3 \%$ of the total population.The proportion of the population living alone was almost twice as low. Such a positive change is observed in both urban and rural areas of Uzbekistan.

It should be noted that the proportion of people living alone was slightly higher in the urban population than in the rural population (table 1)[7-10].

Table 1.

Marital status of the population of Uzbekistan (as a percentage)

\begin{tabular}{|c|c|c|c|c|c|}
\hline Years & 1939 & 1959 & 1970 & 1979 & 1989 \\
\hline \multicolumn{6}{|c|}{ Urban and rural residents } \\
\hline Total population & 100.0 & 100.0 & 100.0 & 100.0 & 100.0 \\
\hline $\begin{array}{l}\text { Including: } \\
\text { Family members living with the } \\
\text { family }\end{array}$ & 93.3 & 95.1 & 95.8 & 94.3 & 95.3 \\
\hline $\begin{array}{l}\text { Family members living separately } \\
\text { from the family }\end{array}$ & 4.4 & 2.7 & 1.9 & 4.1 & 3.4 \\
\hline Lonely people & 2.3 & 2.2 & 2.3 & 1.6 & 1.3 \\
\hline \multicolumn{6}{|c|}{ City population } \\
\hline Total population & 100.0 & 100.0 & 100.0 & 100.0 & 100.0 \\
\hline $\begin{array}{l}\text { Including: } \\
\text { Family members living with the family }\end{array}$ & 85.7 & 91.0 & 91.6 & 90.0 & 91.8 \\
\hline $\begin{array}{l}\text { Family members living separately } \\
\text { from the family }\end{array}$ & 9.6 & 4.9 & 3.8 & $7 \cdot 3$ & 5.7 \\
\hline Lonely people & 4.7 & 4.1 & 4.6 & 2.7 & 2.5 \\
\hline \multicolumn{6}{|c|}{ Rural population } \\
\hline Total population & 100.0 & 100.0 & 100.0 & 100.0 & 100.0 \\
\hline Including: & 95.5 & 97.1 & 98.2 & 97.1 & 97.6 \\
\hline
\end{tabular}


The American Journal of Applied sciences

(ISSN - 2689-0992)

Published: April 30, 2021 | Pages: 256-263

\begin{tabular}{|l|l|l|l|l|l|}
\hline $\begin{array}{l}\text { Family members living with the } \\
\text { family }\end{array}$ & & & & & \\
\hline $\begin{array}{l}\text { Family members living separately } \\
\text { from the family }\end{array}$ & 2.9 & 1.6 & 0.8 & 2.0 & 1.9 \\
\hline Lonely people & 1.6 & 1.3 & 1.0 & 0.9 & 0.5 \\
\hline
\end{tabular}

According to the table, $91.8 \%$ of the urban population lives in the family, while the remaining $8.2 \%$ live separately from the family. This is primarily due to the ethnic composition of the urban population. According to the 1989 census, $31.4 \%$ of the city's urban population were ethnic Europeans, such as Russians, Ukrainians, and Belarusians.It is known that in European nations, such as Russians, Ukrainians, Belarusians, and in the Baltic peoples, it is more common to live alone without a family. This, of course, depends on the traditions of these peoples in the formation and development of the family, the relationship of parents and children in the family. Take Russian families, for example. When a child grows up in a family and gets married, he mainly tries to live independently from his parents. Most Russian families have only 1-2 children, and the parents are left alone because they have started a family and are living separately. Or, as children grow up, they often leave their parents' home to study or work in other cities, leaving both their parents alone.In addition, in many Russian families, the proportion of people living alone is also high as a result of divorce.

The 1989 census showed that in Latvia, 84.8\% of the population remained family members, and $15.2 \%$ lived separately. This figure is 83.2 and 16.8 in Estonia, 87.3 and 12.7 in Ukraine, 87.1 and 12.9 in Belarus, 88.9 and 11.1 in Moldova, 87.4 and 12.6 in Georgia. and in the Central Asian republics it was 95.5 and 4.5 percent. This is mainly due to the fact that in the peoples of
Central Asia, including the Uzbek people, there are more values that bind parents and children, relatives, which are a factor in the strength of the family, its sanctity.

\section{CONCLUSION}

In conclusion, it should be noted that since the second half of the twentieth century, research in the field of ethno-demography has gradually become increasingly important. Research has shown that the family status, composition and social status of the population, especially in ethnic groups, are also influenced by the customs, culture and values of the peoples.

Thus, ethno-demography is a field formed in the field of ethnography and demographic sciences, in which the demographic processes of ethnic groups are studied from a historical point of view. The study of ethnic groups serves as a scientific basis for the development of socio-economic development programs of each multinational state in the world, as well as the study of the values of the traditions of all multinational peoples living in it.

It is known that people of many nationalities and ethnic groups live in Uzbekistan and they are paid attention and respect in the Republic. Each nation has its own language, religion, customs, values, culture, and they, in turn, respect each other's language, religion, culture. That is why, historically, there have been no nationalist conflicts on the territory of Uzbekistan 
Accurate information about the population, dynamics, ethnic processes in a given area is collected through a complete population census. Preliminary censuses provide information on the territorial distribution, education, and gender composition of existing ethnic groups. The role of society in the development of states is unique, because each state consists of a certain nation. By registering ethnic groups in the population and studying their ethno-demographic processes, it is possible to obtain information about the existing socio-economic environment in that society, population composition, social composition, demographic processes, education, level of employment, gender, etc. Ethno-demographic data in population censuses (population dynamics, age-sex composition, births, deaths, migration, marriages, marital status, etc.) are all directly related to each other, and a change in one process inevitably leads to a change in another, they affect each other. For example, the decrease in births affects the whole process in the same way. It leads to an increase in the number of elderly people relative to the number of children in the age group, a decrease in the number of marriages, and an increase in the number of deaths compared to births. Hence, population lists play an important role in accurately knowing the ethno-demographic data on population regeneration.

Population lists also provide information on the marital status and composition of ethnic groups, namely changes in ethno-demographic data depending on the marital status of people in society, the number of people living in the family, their customs, values, lifestyle. Thus, the ethno-demographic data presented in the censuses are important for the study of the demographic history of each nation, its prospects, the development of demographic forecasts. serves as a historical source.

\section{REFERENCES}

1. ЦГА. РУЗ., Ф. 1619, оп. 11. Д - 5. Л - 2.

2. Птух М. Смертность 11 народностей Европейской России в конце XIX в., К.1928.

3. Козлов В.И. Этническая демография. М.: 1977.

4. Брук С.И. Население мира. М.: 1981.

5. Ата-Мирзаев О., Гентшке В., Муртазаева P. Узбекистан многонациональный: историко-демографический аспект. Ташкент. 1998.

6. Буриева М.Р. Рождаемость в Узбекистане. Ташкент. 1991.

7. Всесоюная перепись населения 1939 года. ЦГА РФ, Ф.1, оп. 3, А. 620. л. 73, 78, 79, 80, 81.

8. Итоги всесоюной переписи населения 1959 года. Узбекская ССР. -Москва, 1962. Стр.138-143.

9. Итоги всесоюзной переписи населения 1970 года. T. IV. Национальный состав СССР, часть 1, книга 2, май 1972, стр. 546552.

10. Итоги всесоюзной переписи населения 1989 года. Национальный состав населения Узбекской ССР. - Ташкент, 1990, стр. 51-68.

11. Jabborova Onakhon Mannapovna, Jumanova Fotima Uralovna, Mahkamova Shohida Rahmatullayevna. (2020). Formation of artistic perception of future teachers. International journal of pssycological and rehabilitation, 24(4), 4087-4095. 
12. Mamadaliyev K.R., Jabborova O.M., Umarova Z.A., Abdullaeva B.P. Creation of a New Generation of Teaching Literature A Requirement of Modernity // SCOPUS International Journal of Psychosocial Rehabilitation, Vol. 24, Special Issue 1, 2020.

13. Жабборова Онахон Маннаповна, Ташпулатова Дилором Мукимовна, Бошланғич синф ўқитувчиларига қўйиладиган талаблар. Academic research in educational sciences, Issue 3 , 2021, pp 575-582

14. Gulyamova X. Boshlang'ich sinflarda o'qish darsidan umumlashtiruvchi darslarni tashkil etish. Academic research in educational sciences, Volume 2, Issue 1 , 2021, pp 1052-1060

15. Жабборова О.М., Умарова З.А. Тарбия фанини кластер усулида ўқитишда педагогик конфликтларни бартараф этиш. Academic research in educational sciences, Issue 1, 2021, pp 582-587.

16. Жабборова О.М., Чимпулатова Ч.Д. Бошланғич таълимда Тарбия фанининг кластер усулида ўқитилиши. Academic research in educational sciences, Issue 1 , 2021, pp 562-566.

17. Жабборова О.М., Ташпулатова А.М. Ўзбекистон янги мафкурасининг педагогик талқини. Academic research in educational sciences, Volume 2, Issue 3, 2021, pp 584-589.

18. Умарова 3.А. Бошланғич таълим дидактикаси. Academic research in educational sciences, Issue 2, 2021, pp 556562.

19. Ochilov Fariddunlzatulloyevich, Methods of teaching natural sciences to primary school pupils on the basis of a competent. Palarch's Journal of Archaeology of
Egypt/ Egyptology 17(6) (2020), ISSN 1567214х. 14520-14539бетлар.

20. OchilovFariddun Izatulloyevich, "Atrofimizdagi olam" va "Tabiatshunoslik" darslarini kompetensiyaviy yondashuv asosida tashkil etish jarayonini modellashtirish. The Journal of Academic Research in Educational Sciences, 1(4), (2020). ISSN 2181-1385. VOLUME 1, ISSUE 4. December 2020. Scientific Journal Impact Factor (SJIF) 2020: 4.804. Academic Research, Uzbekistan 2020. 624-629бетлар.

21. Abdullaeva B.P. Babaraximova B.P. Pardaev B.P.Using information and communication technologies in teaching process of various primary European Journal of Research and Reflection in Educational Sciences, 8 (10), 67-70. Progressive Academic Publishing, UK www.idpublications.org 14.10.2020

22. Abdullaeva B.P. Abdullaeva F.T. Organization Of Swimming Lessons In Preschool Institutions THE AMERICAN JOURNAL OF SOCIAL SCIENCE AND EDUCATION INNOVATIONS. JULY 2020[ TAJSSEI]322ISSN (e):2689-100X DOI: https://doi.org/10.37547/tajssei/Volumeo2I ssue 07-42

23. Abdullayeva, B. P., \& Babaraximova, B. P. (2020). MAKTABGACHA TA'LIM MUASSASASIDA FUTBOL DARSLARINI TASHKIL ETISH METODIKASI. Academic Research in Educational Sciences http://ares.uz/jurnallar-sahifasi/ares-vol-1no-3-2020

24. ACADEMICIA: An International Multidisciplinary Research Journal https://saarj.com ORGANIZATION AND METHODOLOGY OF CONDUCTING FOOTBALL LESSONS IN A PRESCHOOL 
The American Journal of Applied sciences (ISSN - 2689-0992)

Published: April 30, 2021 | Pages: 256-263

INSTITUTION Abdullaeva B.P 650-655 10.5958/2249-7137.2021.00098.7

25. Фарфиева, К. А. (2019). Роль третьего сектора в формировании и развитии гражданского общества в Узбекистане.

European science, (3 (45)). 